\title{
Psychological Economics: The Case-Studies of Eurozone, Global Economic Crisis and Greece
}

\author{
Alexandros M. Goulielmos ${ }^{1,2}$ \\ ${ }^{1}$ Department of Maritime Studies, Marine Economics University of Piraeus, Piraeus, Greece \\ ${ }^{2}$ Maritime Division of Business College of Athens, Athens, Greece \\ Email: ag@unipi.gr, am.goulielmos@hotmail.com, agoulielmos@bca.edu.gr
}

How to cite this paper: Goulielmos, A.M. (2018) Psychological Economics: The CaseStudies of Eurozone, Global Economic Crisis and Greece. Modern Economy, 9, 1792-1820. https://doi.org/10.4236/me.2018.911113

Received: October 8, 2018

Accepted: November 12, 2018

Published: November 15, 2018

Copyright $\odot 2018$ by author and Scientific Research Publishing Inc. This work is licensed under the Creative Commons Attribution International License (CC BY 4.0).

http://creativecommons.org/licenses/by/4.0/

\begin{abstract}
We showed what Economics owes to Psychology ... in Microeconomics with utility and in Macroeconomics with the 4 propensities to consume, to save, to invest and to hold cash. Psychology is a science in-the-making, but par excellence essential in Keynes' model. Keynes' 3 independent variables-consumption, rate of interest and marginal efficiency of capital, are presented (in the appendix). We also derived a "demand curve" for goods, using "Pareto's power law". We showed (partly) Keynes' microeconomics, something which many argued Keynes lacked. We took-in addition-the opportunity to use Hicks' IS/LM curves. Moreover, we used the "Swan-Solow" diagram. These 3 diagrams helped us to present the situation in Eurozone, in our country Greece, and from the impact of the "Global financial crisis" (GFC) since end 2008, drawing on Temin \& Vines [3] and ... of course on Keynes [1]. We saw that emphasis in the quality of goods, which we consume, and in the proper attention to the environment, we live, was largely absent! Economists escaped from their half responsibilities by an alibi saying that: our science is "about what is"...
\end{abstract}

\section{Keywords}

Psychology in Microeconomics-Utility, Keynes' Four Macroeconomic Psychological Propensities, Keynes' Microeconomics, The Demand Curve from "Pareto's Power Law", Hicks' IS/LM Curves, Swan-Solow Diagram, Eurozone-Greece-GFC-Case-Studies

\section{Introduction}

Economics is a social science, despite its occasional flirt with Physics and Mathematics. Humans, by majority, live in communities. Apart from any sociological aspects, when humans act economically their psychological background is 
important. Keynes (1883-1946) [1], advanced 4 human "psychological propensities"-called also laws. Not all economists based their analysis as firm as Keynes on Psychology. He also distinguished his propensities from the less permanent "habits", which even they required enough time to adapt to changed conditions. Moreover, it was Psychology which made Keynes' economic system stable! Keynes, par excellence, feared the (psychological) instability inherent in "laborers" and "capitalists" (expressed in Keynes' "the Economics of Peace" in 1919).

In classics, the main Scottish Philosopher Hume D, (1752) ${ }^{1}$ (1711-1776) was influential. For Hume the methodology of any social science is largely applied psychology ... Also, the motives of "self-interest" and the "desire to accumulate wealth" are the main economic forces. Hume greatly influenced Adam Smith (1723-1790). Hume's law-under Gold Standard—stated that "purely automatic forces tend to establish a natural distribution of species between trading countries", where the "level of domestic prices will be such that each country's exports become equal to its imports" [2] [3].

Economists are ... revolutionary dealing with 4 revolutions: the "industrial" ( 1790), "marginal" (1870s), "Keynesian" (1936) and "Managerial" (1967)². The Marginal revolution is related to "diminishing marginal utility" [2]. Managerial revolution is due to Galbraith (1908- ), where the economic power passed from "Capital" to "Managerial class". Economics [2] have many ... "laws", some flirting clearly with Physics, the: natural ${ }^{3}$, diminishing returns; comparative cost; Say's; production; distribution; Hume's (mentioned above); motion of capitalism; falling rate of profit; return; rent; Gossen's $2^{\text {nd }}$ one and Keynes' four laws.

Gossen's [4] $2^{\text {nd }}$ law is quite modern: "a person maximizes utility, when distributes available money among various goods to obtain the same amount of satisfaction from last unit of money from all goods" [2]. In addition, Gossen [4] formulated the concept of marginal utility, and drew the negatively inclined curves of marginal utility and demand.

The "capitalistic law of motion"- due to Marx-argued that the system creates wars, colonial exploitation and waste of human resources -due to unemployment [2]. For the "law of the rate of profit", p, Marx argued that this is a function of the "organic composition of capital", $q$, and the "surplus value" $\sigma$, where $\mathrm{p}=\mathrm{s} / \mathrm{c}$ $+\mathrm{v}$, \& by

$$
\text { definition }=\sigma / q+1
$$

where

$$
c+v+s=G N P
$$

(where GNP = gross national product), and $\sigma$ by

$$
\text { definition }=s / v
$$

the flow variables are: $c=$ constant capital, $v=$ wages, $k=$ total capital outlay and ${ }^{1}$ Believing in "Quantity theory of money".

'Other revolutions in: "telecommunications"; "information"; "computerization" and "digitalization". 3"Normal" or "just" law: a set of rules imposed by nature, as argued by Catholic Aquinas $\mathrm{T}$ (1225-1274) -follower of Aristotle, and an early Physiocrat (1694+), believing in "social" necessity. 
$s=$ surplus value.

Economics became a science solving the problem of "limited resources against a plethora of needs". But, it ignored the resource allocation, level of prices and incomes, and population growth. We all know that human needs cannot be satisfied once and for all ... Total satisfaction can be derived through a "constrained maximization process" ... For economists, satisfaction is ordered, expressed in "indifference" curves ${ }^{4}$... stating human preferences! The consumer is aware about the fact that by consuming a small extra amount of a good A, dCA, he/she derives a small amount of utility,

$$
\mathrm{dUA} \text { or Marginal utility }-\mathrm{MUA}=\mathrm{dUA} / \mathrm{dCA}
$$

Modern economists ${ }^{5}$ turned indeed the economic system into harmony, by dismissing class conflict, which has been introduced by Marx, based on Pareto. Also, “Monetarism" (1968; Friedman 1970s), "Rational Expectations" (1983) and “Game theory" (1948), pushed Keynes' theory aside ... In the 1990s, however, markets were unstable-after being stable for 45 years soon after $2^{\text {nd }} \mathrm{WW}$ ! Economists re-visited Keynes [3] [8] [9]. Looking at history, erroneous Philosophers and false religions damaged world peace by believing: first, that man comes from the ape (Darwin, 1809-1882; 1859); then that classes must conflict (Marx K; 1818-1883; 1867-1894; “one class must rule”); next, that races must conflict (Hitler A; 1889-1945; "one race must rule") and now, that one religion must fight against all others (Terrorism) ("the religion of Allah is the only great")!

Looking at present, we wondered: is now the end of "globalization"? Can the world become "one village", given the beneficial effects from international trade liberalization (since 1994) and the elimination of trade tariffs? USA fell back - under Trump administration-from its past economic policies, so that now to promote its national interests. USA resorted to protectionist measures, (rising import tariffs), at the expense especially of China, Mexico, Germany and EU. Most important is the threat against the integrity of global climate. USA's impact will be no small as it is large economy ... A better globalization could have used the lower costs achieved in final goods produced (and especially in raw materials) (made-in) at globalized locations, to benefit those countries (having a low level of standard of living), where this production took place. This could be attended by GTO.

\footnotetext{
${ }^{4}$ The "Indifference" curves-ICs invented by Edgeworth (1845-1926) in 1881 (in his book ... titled "Mathematical Psychics"!); ICs refined by Pareto (1848-1923) and Fisher (1867-1947) and revived by Bowley (1924) [5]. In 1934, Hicks and Allen showed that ICs can reconstruct the theory of "consumer behavior" from "ordinal utility"; this showed before by Johnson [6] (1913) and Slutsky (1915) (1880-1948) [7]. Slutsky [7] in particular argued that demand theory can be based on ordinal utility. ${ }^{5}$ Clark J M; Edgeworth F Y; Fisher I; Marshall A; Pareto V; Walras L and Wicksell K are the neo-classical economists (Pearce (1992) [10]). The neo-neoclassical ones were (for us): Von Neumann and Morgenstern (1944), Samuelson P (1948), Solow R (1956), Friedman M (1976), Nash J, Hicks J (1937; 1946), Modigliani (1985), Patinkin D (1948), Debreu (1983), and others. This list is not complete.
} 
The above idea was also behind “UNCTAD's code of conduct known as rule "40-40-20"-implemented within 20 years or so-in the allocation of cargoes, where $40 \%$ of them reserved for exporting countries/their vessels ("UNCTAD's Code of conduct for liner conferences" is in force since 1983).

Keynes aware about the need of "international effective demand" for exports suggested providing loans (to other countries) to import (and ... Germany to export). Instead (for us) advanced countries should help the less developed countries by exporting technology to them, so that their domestic production to become competitive. Imagine the situation of the Eurozone where currency parity is fixed and domestic production has a substantial "import content/cost" (e.g. Greece).

Looking at Eurozone, it proposed "austerity", i.e. to achieve a lower cost domestic production, mainly by reducing wages, (what if wages are a small \% of total cost?). To replace imports by domestic production, and to boost exports, this is a "dream in a summer night" for Greece, we believe. Moreover, dearer food and goods from imports in Greek super-markets and elsewhere (petrol stations; car-sales; chemists etc.) — apart from the increased VAT imposed by Greek government-deteriorated standard of living from 2 sides: lower disposable incomes and wages and high "domestic" prices! They say: wait for lower wages to reduce domestic prices ... we say as Keynes said: "in the long run we will be all dead".

The paper is organized as follows. Next is a literature review, followed by methodologies; then, part I: "Psychological Microeconomics. Next, part II: "Psychological Macroeconomics". Then, part III: “Keynes' Microeconomics” followed by part IV: “Hicks' curves”. Next, part V: “Eurozone, Global Economic Crisis and Greece". Finally, we conclude.

\section{Aim of Paper}

This paper focused on "Psychological Economics". Human psychology is very helpful, we believe, for economists to understand fuller the human economic nature. Like engineers, who study economics, economists should study psychology, we reckon ...

We separated the psychological foundations from their economic superstructures and revealed the importance of human psychology in economic decisions. We showed that the one disadvantage of capitalism-comparing with communism-is that humans do not consume the entire income they earn-out of psychological motives - after they reach a sufficient "standard of living" (Keynes).

The other disadvantage is that Savings may be in dis-equality to Investment, where those who save and those who invest are different people, with different psychology and ... free will. Economics has to bridge this gap for the attainment of growth. For this reason, Macroeconomics became a science after 1936.

Microeconomics became also a science to solve the problem of a plethora of needs vis-à-vis limited resources. But this was not the most important, as 
Economists discovered early in the history of economic science (1854) the "disutility of labor", meaning that no one likes to work...But economists found the counter-measure: work provides income and income allows for consumption and consumption provides satisfaction ... utility. And the most important: utility can be maximized mathematically!

Business firms and Marketing-as we showed-follow consumers and users' psychology to derive from them maximum profit. But the quality of life and the quality of consumption goods slipped away ... to a great harm of human beings. It is high time to re-define the objectives of economics from profit and utility maximization to a healthier environment and food ...

\section{Literature Review}

"Utility", an essential psychological concept, is the ingredient we found in almost all economic recipes! Three (!) economists arrived at utility (marginal), independently one from the other: Menger (1840-1921) in 1871, Walras in 1873 (1834-1910) and Jevons (1835-1882) in 1871.

Initially, the above saw no relationship between utility and demand. Menger and Walras, in particular, treated the existence of a yardstick for measuring utility rather easy ${ }^{7}$. Jevons denied that utility is measurable, but then suggested a way to measure it via the $\sim$ constancy of the marginal utility of money ${ }^{8} .$. Menger and Walras saw no difficulty in comparing the utility of different consumers.

They believed that the utility of a good is a function of its quantity-which is partially true for us. Moreover, the "law of diminishing marginal utility" considered one derived from "common experience" [2].

First Gossen [4] formed the principle of marginal "disutility of labor" (Figure 1): a “divine law" [11].

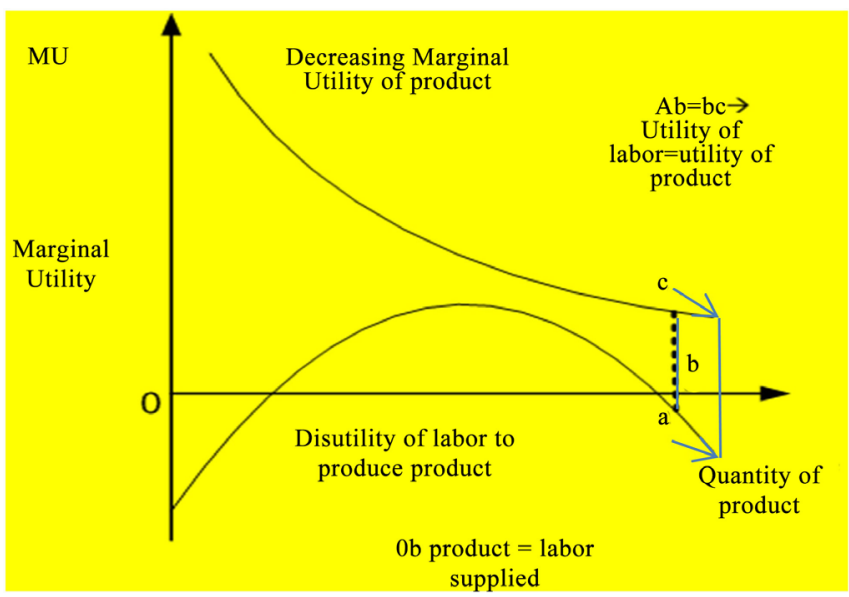

Figure 1. Disutility- $D U$ of labor versus satisfaction $U$ from consumption.

Source: Modified from that in Blaug [2]. where: $M U_{\text {product }}=M D U_{\text {labor }}$ (5).

${ }^{6}$ Reference to "marginal utility" theory per se, is rare...in economics!

${ }^{7}$ This problem "tortured" Economics for decades till "order" replaced "cardinality".

${ }^{8}$ I.e. the marginal utility of income; the rise in utility, as income rises by one unit. 
The concept of diminishing marginal utility, as applied to income, based on egalitarian principles [4]: economists wanted to establish economic equality among humans, so that human justice to be awarded. Moreover, Edgeworth ${ }^{9}$ showed (in 1881) that human happiness can be measured as a 2-dimensional quantity given intensity and time involved!

Smith A in 1776 equalized total utility of goods to their "use value". For him, utility is the property of a good to satisfy a biological, or social, need [2]. Locke J, Law J and Harris J contrasted the value of "water" with that of "diamonds"- the famous paradox of classics-to show that relative scarcity (=cost of production in the long run; demand and supply in the short run) governs value, irrespective of good's usefulness [2]. The price of a good is the province of the forces of demand and supply, something, however, incompatible with "marginal revolution".

Ricardo (1772-1823) altered the implicit meaning of Smith's "use value" naming it "utility". Utility for him is the capacity of a product to contribute to human gratification [2]. Cournot A (1801-1877) and Cassel G (1866-1945) employed a demand function without a utility substructure [2]. Jennings R. [12] stated the principle of diminishing marginal utility in the form of a law derived from the variation of sensations; something we consider sensible.

Utility adopted also by Marshall [13] but refined. Marshall's statement (in 1890) of utility theory is considered superior ${ }^{10}$ to that of both Jevons and Walras. $\mathrm{He}$, after Walras, clearly and explicitly, derived demand curve from utility function (his mathematical appendix II):

"The equilibrium condition for consuming good X-and all goods-for Marshall is:

$$
M U_{X}=P_{X} M U_{\text {money or expenditure }}
$$

where $P_{X}$ is the price of good $X, M U_{X}$ is the marginal utility of $X$, and $M U_{\text {money or }}$ expenditure is the marginal utility of money (or expenditure). The more of $\mathrm{X}$ is bought, the less $M U$ is obtained [2]. In fact, Marshall equalized "quantity bought" with "quantity consumed" ... given income and price of the good.

Marshall [13] argued-by the way-that a stronger incentive is required to induce a person to pay a given price, if he is poor, than if he is rich. The less one has, the more what has is precious for him, and vice versa, excluding miserliness. Thus, a heavy taxation to rich is not the same thing, psychologically, to poor.

As argued by Schroeder [14] measurement-in classical physics-is a well-understood process, relating an "observed quantity" to a well-defined "unit". Stevens S. [15], introduced measurement methods into psychology considered nearly as unambiguous as an objective measurement in Physics. He used ratio scales to subjective variables ("loudness", "brightness"), and discovered simple power laws between them and their corresponding physical quantities

${ }^{9}$ He succeeded Senior in Oxford University.

${ }^{10}$ Contributions made by Fisher I, with his essay: "A statistical method of measuring marginal utility and testing the justice of a progressive income tax" (in 1927) and his doctoral thesis: "The mathematical investigation in the theory of value and prices" (in 1892). 
("energy flux", "intensity"). Stevens' theory, we reckon, could be used by economics related it to "human needs".

Let us relate the intensity of a need to its demand. Assume a need $\mathrm{H}$ to be that for food, having intensity I, and suppose I increased due to the long time elapsed from last meal. Need's intensity is multiplied by 10 . So, $\log 2=\sim 0.3$ rounded $(=0.30103)$, and the power law for $H$ is a function of need's intensity:

$$
H=I^{0.3}
$$

This can be also an "observed" power law for $\mathrm{H}$ versus need's intensity $I$ and can also be predicted by a statistical model using "neural firing rates" [14].

Robinson and Eatwell [16] argued that utility is what makes consumers to buy, and by consumption, to enjoy utility ... The consumer maximizes utility by allocating income among various goods. Neo-neoclassicals recognized that "utility" is not an operational concept, and that "revealed preference"-due to Samuelson [17] - was better for an empirical basis for consumers' demand [16].

Blaug [2] argued that making utility the explanation of consumer's behavior, the founders of the subjective "theory of value" ran into a double-barreled opposition: $\mathrm{it}^{11}$ rests on bad, or at least questionable, psychology, and the psychological aspects of consumer behavior are irrelevant to the objective facts of economic process, running irrespective of any individual feeling.

Csikszentmihalayi [18] argued that his main findings after 20+ years of research are that: "happiness" is a "flow": a feeling that everything is going (just)

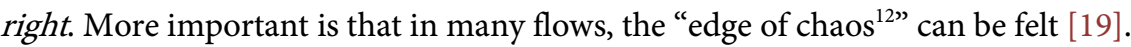

In summary, economists massively supported the psychological concept of utility since 1870s, but Samuelson. Utility, however, as a concept, had to help to solve a problem: "given economy's productive services, how one can allocate them to obtain optimal results"? Answer: maximize consumers' satisfaction. Jevons put also the same question (in 1862): "how one can employ labor by maximizing the utility of produce"?

Economists tried to find "compensating" alternatives to human misery, we believe: "disutility from work" compensated by utility from goods' consumption ... "Life's misfortunes", compensated by happiness, derived from the satisfaction from consuming goods ... With one stone killed two birds.

\section{Methodologies}

The "psychological" variables we found in economics are listed ${ }^{13}$ in Table 1, relying on their authors for such characterization. We only restricted our research to "Microeconomics" and "Macroeconomics": a distinction which appeared first

${ }^{11}$ For the "theory of value", a good has intrinsic worth; it must possess utility, or usefulness, to be produced or exchanged. The late $19^{\text {th }}$ century neo-classical economists focused on the determinants of market price, which was marginal utility... Moreover, demand and supply derived from utility.

${ }^{12}$ It describes the zone, in a complex system, when an ordered behavior gives way to a turbulent one; i.e. there is a "phase transition". There are 4 classes of behavior in complexity science: "stasis, order, chaos, and complexity".

${ }^{13}$ Psychology $=$ the science of nature, of functions, and of phenomena of human mind and conduct. 
in Keynes [1].

"Pareto's Power Law": let

$$
P(u)=(u / m u)^{-\alpha}
$$

where $P$ is the proportion of people earning more than maximum income $u$, and alpha is a (negative) power law. E.g. for $u=\$ 107,120 /$ year maximum and for the $\%$ of people earning that, this stands for $u=10 \mathrm{~m}$, where $\mathrm{m}$ stands for minimum income. Then $10^{3}=1000$ and $\sqrt{ } 1000=31.6$ and $1 / 31.6=3.2 \%$. So, according to Pareto's power law, a small \% (3.2\%) of population earns maximum income/year ...

\section{Part I: Psychological Microeconomics}

\subsection{Utility and Satisfaction: A New Theory of Wants?}

Utility and Satisfaction are different. An unsatisfied need creates unhappiness, till is satisfied. Apparently, there is a discrete consumption, releasing "doses" of happiness, mainly to body ...

Economists argued that the "satisfaction from the consumption of a quantity $\mathrm{Q}$ of a good A at time $\mathrm{t}$, is a function of the quantity consumed:

$$
S_{t \text { from good } A}=f\left(Q_{\text {good A consumed }}\right)
$$

Classics believed that a good-if useful-provides a need's satisfaction. Robinson J. [20] argued that utility is a circular concept.

\begin{tabular}{|c|c|c|c|}
\hline $\begin{array}{l}\text { Animal spirits; the } \\
\text { psychology of the } \\
\text { enterprise }\left(^{*}\right)\end{array}$ & Axioms & Basic needs philosophy & Bounded rationality \\
\hline Brand loyalty & $\begin{array}{l}\text { Consumer's surplus }\left(^{*}\right) \\
\text { (analyzed but not fully) }\end{array}$ & $\begin{array}{l}\text { Expectations = beliefs or } \\
\text { views on future values of } \\
\text { economic variables }\end{array}$ & $\begin{array}{l}\text { Expected utility theory/ } \\
\text {-prospect theory }\end{array}$ \\
\hline $\begin{array}{l}\text { Heterogeneity; } \\
\text { homogeneity }\left(^{*}\right)\end{array}$ & Just price & Money illusion & Perfect information \\
\hline $\begin{array}{l}\text { Permanent income } \\
\text { hypothesis }\end{array}$ & Revealed preference $\left(^{*}\right)$ & $\operatorname{Scarcity}\left(^{*}\right)$ & Time preference $\left(^{*}\right)$ \\
\hline $\begin{array}{l}\text { Utility and utility } \\
\text { function }\left(^{*}\right)\end{array}$ & Utilitarianism & Value, theory of $\left({ }^{\star}\right)$ & Value management \\
\hline Vertical equity & $\begin{array}{l}\text { "Von } \\
\text { Newmann-Morgestern" } \\
\text { utility }\end{array}$ & Want creation & Willingness to pay $\left(^{*}\right)$ \\
\hline $\begin{array}{l}\text { Keynes’ } 4 \\
\text { fundamental } \\
\text { psychological laws }\left(^{*}\right)\end{array}$ & $\begin{array}{l}\text { Mass psychology of } \\
\text { investors }\end{array}$ & $\begin{array}{l}\text { Workers seek a much } \\
\text { higher "money-wage" }\end{array}$ & Multiplier $>1\left(^{*}\right)$ \\
\hline $\begin{array}{l}\text { The Psychological } \\
\text { factors for stability }\left(^{\star}\right)\end{array}$ & Pareto’s power law $\left({ }^{\star}\right)$ & Supplementary cost $\left({ }^{\star}\right)$ & Total 34 \\
\hline
\end{tabular}

Table 1. The psychological concepts in economics. $\left(^{*}\right)$ indicates further analysis.

Source: selected from [10]. 17 of them will be presented. 
However, Equation (9) is not accurate, and better be: "satisfaction at time $t,\left(S_{t}\right)$, from consuming quantity $Q_{t}$ of good A-in order for a need to be fully satisfied for the time being-is also a function of need's intensity. It mentioned in literature review-apart from quantity Qt - and of time t elapsed since need satisfied:

$$
S_{t A}=f\left(Q_{A \text { Cons } .}, I_{t}, t\right)
$$

More fully:

$$
\text { Need }=f
$$

(I, income, cashable wealth, prices, advertising, quantity, time).

Utility is a potential ability - real, imaginary or spatial —of a good to satisfy a need. Regrets exist. Utility rather provides a promise and a hope towards satisfaction. If the intensity of a need is zero, the "quantity demanded" should be also zero.

States of miss-happiness in economic life should be allowed. Constraints prevent happiness: lack of disposable income and/or cashable wealth, lack of opportunities, high prices ... In addition, worth noting is that the more fully, frequently, and deeply one satisfies a need, the more intense the same need returns, demanding also variety ...

Causes create needs ${ }^{14}$, and needs cause economic wheels to go round, making people to spend; firms try to find ways (e.g. promotion) to convince people to spend. If a need is already satisfied for a good, whose price soon thereafter falls, demand for it is nil [21]! So, it is not always valid to say that "as price falls, demand increases". Also, a given income or wealth buy more goods, if prices fall ("income" and "wealth" effect) (motive on which sales and discounts etc. are based).

\section{2. "Income and Effective Demand"-A Case-Study}

Let relate income earned to effective demand, with a view to derive a demand curve ... Assume a starting company paying now to each of its 250 employees $€ 893$ (rounded) per month. Table 2 shows the way company's wages will be modified as time goes-by. In fact, "Pareto's power law" is applied.

Table 2. The distribution of salaries among 250 employees of a hypothetical starting company over time.

\begin{tabular}{ccc}
\hline Monthly salary $€$ & \% of people receiving it & Total expenditure $€$ \\
\hline $893=$ average to start with & 100 & 250 persons $\times 893=223,250$ \\
$1786(\times$ double $)$ & 35 (rounded $)$ & $\sim 87$ p. $\times 1786=155,382$ \\
$2679(\times 3$ times $)$ & 19 & $\sim 47$ p. $\times 2679=125,913$ \\
$3572(\times 4$ times $)$ & 12.5 & $\sim 31 \mathrm{p} . \times 3572=110,732$ \\
$4465(\times 5$ times $)$ & 9 & $\sim 22 \mathrm{p} . \times 4465=98,230$ \\
$8930(\times 10$ times $)$ & 3.2 & $8 \mathrm{p} . \times 8930=71,440$ \\
\hline
\end{tabular}

Source: Calculations using Pareto's power law.

${ }^{14}$ Snobbery, anxiety and sexual association play a major part in influencing consumers' choice (Robinson \& Eatwell [16], p. 203). 


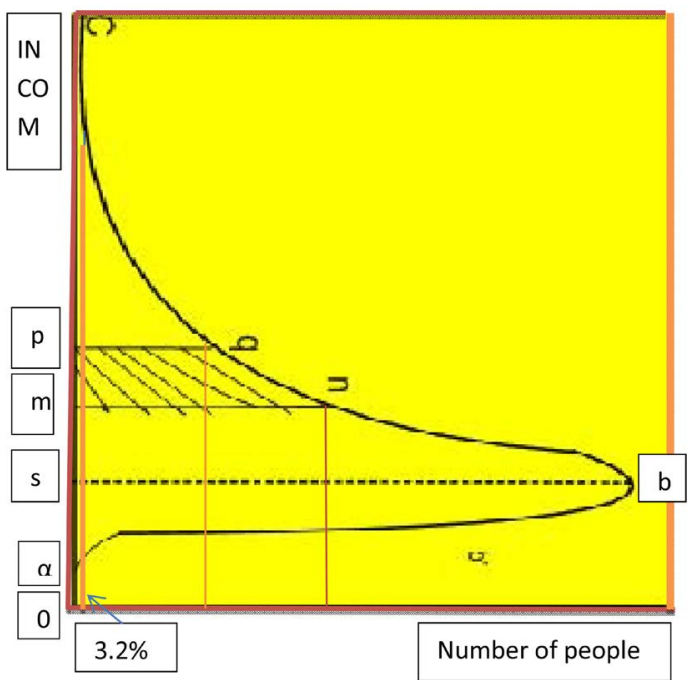

Figure 2. Pareto's 1909 diagram of income distribution. Note: "pqnm" shows the number of employees receiving income between $\mathrm{p}$ and $\mathrm{m}$. The distribution is not symmetrical. sb is the average income earned by the mass of employees. $0 \mathrm{C}$ is earned by only $3.2 \%$. Not a "social pyramid" or not fair ${ }^{15}$ ! Pareto attributed this to "nature of man"!

As shown, the highest income per head in the company is paid eventually to only 8 persons (last entry). This hypothetical company started with equal salaries to everybody, but eventually initial salaries were modified. We will not analyze the reasons for this (Figure 2).

The highest income is $0 \mathrm{C}$. The majority of employees, i.e. $76 \%$, earn, a lower wage, equal to $0 S$.

\subsection{Income Earned and Spent}

If now we relate personal income earned to the amount spent, the curve derived (=effective demand) is a line falling from left to right (Figure 3).

\subsection{Homogeneous Products}

Let a well-known equilibrium model of a firm under perfect competition (Figure 4) be:

As shown, a firm is in equilibrium when

$$
M C=A C=M R=\text { Price }=A R
$$

The firm maximizes "profits" (i.e. "normal"). Economists avoid defining "normal" profits, but let them be $10 \%-15 \%$ on cost. The "monopoly profits" (super-normal) are $0^{16}$. One condition, however, for normal profits, is the product to be homogeneous ${ }^{17}$.

${ }^{15}$ Pareto V born in 1848 in Paris and died in 1923 in Geneva: Italian industrialist, and sociologist; he became economist in his forties; educated in Turin; taught in Lausanne. He started as liberal; ended as a student of socialism. He turned economics from a branch of social philosophy (due to Smith A) into a data-intensive field of scientific research and mathematics. He studied how power and wealth (2006; preface 2008) [22]) are distributed among people.

${ }^{16}$ Economists confuse people when they say that "profits" are zero meaning monopoly ones!

${ }^{17}$ The other is free entry. 


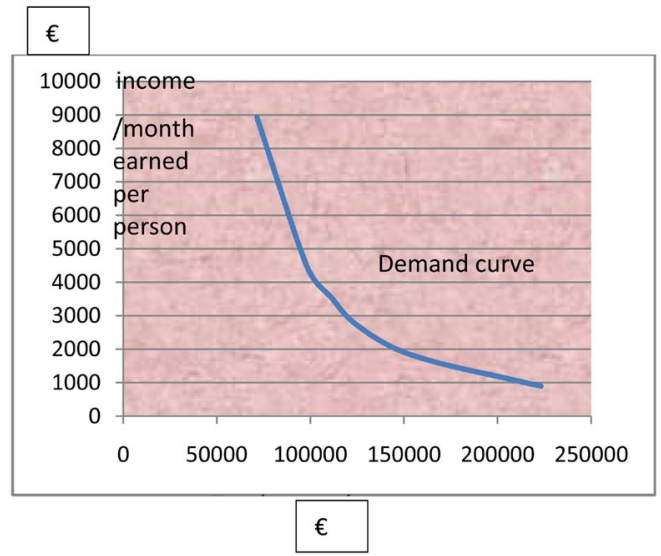

Figure 3. Total income earned and spent. Source: Table 2; excel; Pareto's power law.

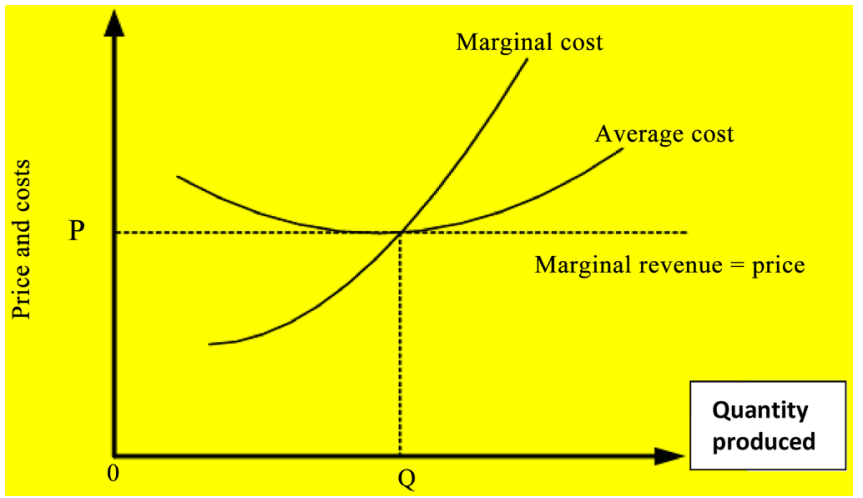

Figure 4. Firm in equilibrium under Perfect competition. Source: Author.

But what if the firm is not happy with normal profits? Price is determined by demand and supply, and is given (=price-taking). Firm then thinks: if our product was not "homogeneous", could we increase price (and earn "super-normal" profits ...)? But first what is homogeneity- $\mathrm{H}$ ? $\mathrm{H}$ is the property of goods to have identical attributes ... in the eyes of buyers-psychology again. A good is different ... than an identical one, if one believes it is ... A vessel old-but well-maintained-is seen as inferior, vis-à-vis a younger one, for the probability in mind that she might cause a marine accident ...

Example: in TV is shown that by drinking a certain brand of whiskey it results to ... live together with a nice tall woman; one has to pay extra for this product or prefer it. So, advertising studies human needs (and passions) and promotes

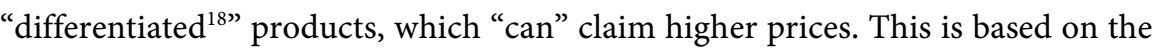
principle: "we are not all the same" and "we are better"!

Shaw [23] wrote that airline companies want to understand the factors that customers take into account in making their minds-up ${ }^{19}$. He found that users try to maximize personal benefit, and airline companies have to pander their pride, greed and ego; some users are lazy; companies try to exploit the weaknesses of ${ }^{18}$ Advertising has a number of means to do that using the 8 or so Ps: product, place, price, promotion, people, package etc.

${ }^{19}$ Needs are distinguished in "apparent" and "true". 
human personality, which are relatively constant. Keynes counted on this constancy.

In addition, users in airlines want to gain maximum utility from their service status; their wants are distinguished in tangible and psychological, like their desire for recognition. Airline companies refer also to psychographics, i.e. finding those intangible attitudes, preferences, and prejudices of people ...

\subsection{The Willingness to Pay}

Every buyer has a "personal" demand curve. This relates a series of hypothetical prices to various quantities for which he/she is willing to pay for than going away empty-handed. This demand can be estimated by market ${ }^{20}$ research. This information, however, is very valuable, especially about the maximum price, where quantity is positive.

Accordingly, if a firm knows the exact maximum price buyer is willing to pay for, why not charge it ...? In certain economists and especially in Marshall [13] and after), this idea is related to "consumer's surplus", but their demand curve and Marshall's touch the vertical axis implying there zero willingness to pay ... and zero demand.

\section{Part II: Psychological Macroeconomics}

Keynes ((1883-1946) [1] embodied psychology ${ }^{21}$ into macroeconomics, in general, and into business economics, in particular. He also formed a microeconomic theory (part III). Keynes [1] wanted not only his theory to be theoretically correct, but also to rest heavily on his experiences (Chapter 18), belonging to Marshall's ${ }^{22}$ school.

Keynes drew on the "actual phenomena" of the economic system colored by 4 special characteristics. For him [1] the "psychology" of the society: meaning its psychological characteristics (propensities) - is such that when total (real) income Yt (and employment $\mathrm{Nt}$ ) increase, consumption Ct increases, but not as much:

$$
d C_{w} / d Y_{w}>0 \text { and }<1
$$

(where $\mathrm{w}=$ wage units) or [1]

$$
d C_{t+1, w} / d Y_{t, w}>0<1
$$

Though Equations (13) (14) are valid-after a certain level of income ${ }^{23}-$ Keynes simultaneously introduced the main pathology of the capitalistic system! Society does not consume all of what is produced. The above law allows for Savings in $\mathrm{t}+1$, but it makes "effective demand" $<$ than last year's total income, $\mathrm{Yt}$ ${ }^{20}$ Coastal shipping companies want to apply different pricing to a student, family, tourist, poor, cyclist, motor bike, pedestrian, business man, etc.

${ }^{21}$ Keynes did not use "rationality" ... a case where one behaves by maximizing utility ... or blackboard theorizing.

${ }^{22}$ It is interesting to see how carefully Marshall [13] uses mathematics and geometry-confined in appendices - for the danger of parting from reality ...

${ }^{23}$ Keynes assumed this to hold after a "standard level of living". 
- 1. This leads a capitalistic system to recession ${ }^{24}$ ! This is the "paradox of thrift", and the main disadvantage of capitalism. Keynes was not only convinced for the reality of Equations (13) (14), but he also considered them as key to his practical problems (p. 65), and used them for stability (p. 130).

Classics did not deny Savings, but they assumed to be automatically invested (their "loanable funds theory") via the rate of interest-r.

\subsection{The Position of KEYNES (Briefly)}

In the French edition of General Theory, (1939, Feb., preface), Keynes argued that: "if we know the propensities to consume and invest, and the result of the individual psychological trends (in disposing given income), we can calculate the level of income, and consequently the level of production and employment, in balance with profits, under a given level of investment" (bolds and () added).

\subsection{The Ultimate and Independent Psychological Variables}

For Keynes [1] the 4 "ultimate" and "independent" psychological variables are:

- the propensity to consume,

- the attitude to liquidity,

- the expected yield from capital assets, and,

- the psychological propensity to save.

For Keynes [1], the propensity to consume is the fundamental psychological law and the permanent psychological trend, on which (he) rested with great confidence, due to his knowledge of human nature ... and his detailed experiences ... (bolds and () added). Moreover, the "psychological" "time preference" refers also to the propensity to consume [1], where, if all income is consumed, spending in $t+1$, is prevented (and no interest is gained). For, if all resources are devoted to consumption, nothing is left $\mathrm{f}^{25}$ for investment.

Mature societies consume part of their income; as their "most basic ${ }^{26}$ needs" are satisfied, and (their) income increases over time, based on human nature. Savings are a "blessing", but at the same time ... a "curse". Classics believed wrongly that what is good for an individual is good also for an economy ...

In USA (2017) those with 0 incomes were $1 \%$ of the population $(\sim 325,700$ persons); and $19 \%$ saved ... $0 ; 21 \%$ saved $5 \% ; 36 \%$ saved $6 \%-10 \%(25 \%$ of the population) and $11 \%-15 \%$ (11\% of population); and $16 \%$ saved $>15 \%$ (total

\footnotetext{
${ }^{24}$ In a Marxian system humans had a planned-by the state-frugal consumption; State saved and invested. Firms and governments in capitalism save. Everybody earning income (and profits) and collecting money (taxation) etc. out of current production, he/she must spend it entirely to maintain $\mathrm{Yt}-1$. Savings must go to banks-or to bonds or to shares-having the main purpose to lend people wanting to invest. Governments and firms are also consumers (e.g. governments spend for space programs; wars; for unemployment benefits; investment; housing programs, pay loans to other states, etc.).

${ }^{25}$ Firms save through "depreciation" = past profits retained to be invested sometime in future. In USA, depreciation, plus other items, classified under "net capital formation", were steady and high -between 1925 and 1929 (crisis start) -between 25\% and 26\% ([1] p. 103) on an amount of \$33b gross capital formation.

${ }^{26}$ The "basic needs philosophy" sets priorities to societies.
} 
93\%; 7\% stated ignorance or refused to answer) (source: Bankrate.com). This despite increased money wages and fall in unemployment.

Moreover, people under 30 years saved 0 in Canada; 10\% in Germany; 10\% in Italy; $18 \%$ in Japan; $5 \%$ in UK; dis-saved $2.2 \%$ in USA. Thus Japan seems to be a more mature society among young people, who suffer more by unemployment.

\subsection{The Propensity to Consume (Mathematically)}

The functional relationship, $f$, between income $Y_{w, t}$ and expenditure from it $C_{w, t+1}$ on consumption goods, is:

$$
C_{w, t+1}=f\left(Y_{w, t}\right)
$$

([1] p. 90-91). Equation (15) indicates that income has first to be earned. This further means that employment has to be provided first for one to be entitled to income. National income, $\mathrm{Yt}$, is determined by national employment,

$$
N t \text {, or } Y_{t}=f\left(N_{t-1}\right)
$$

\subsection{The Factors of Consumption}

Consumption, according to Keynes, depends on 8 subjective factors -including the psychological characteristics of human nature, which more important are unlikely to undergo a material change in the short run. Keynes [1] devoted a whole chapter (num. 9) to list the reasons why the entire income will not be spent (during $t+1$ ), indicating the emphasis he put on:

- to build-up a reserve for unforeseen circumstances;

- to put aside an amount for: old age, family's education \& maintenance of dependents;

- to keep an amount for gaining interest etc.;

- to enjoy an increasing future expenditure;

- to enjoy a sense of independence;

- to accomplish speculative actions or businesses;

- to bequeath a fortune, and,

- to satisfy miserliness.

\subsection{The Disadvantage of Capitalism}

Let us see closer what we have called the "disadvantage" of capitalism (Figure 5), due to the increasing Savings, as income increases. A capitalistic economy depends on investors, and increasingly so, if we place time on horizontal axis. There is, however, an advantage in capitalistic system that certain individuals -and not the state-will become richer, as time goes-by increasing their wealth. There is, however, a solution to maintain yesterday's income: the gap between current consumption Ct and yesterday's income $Y t-1$, to be filled by current investment

$$
Y t-1=C t+I t
$$




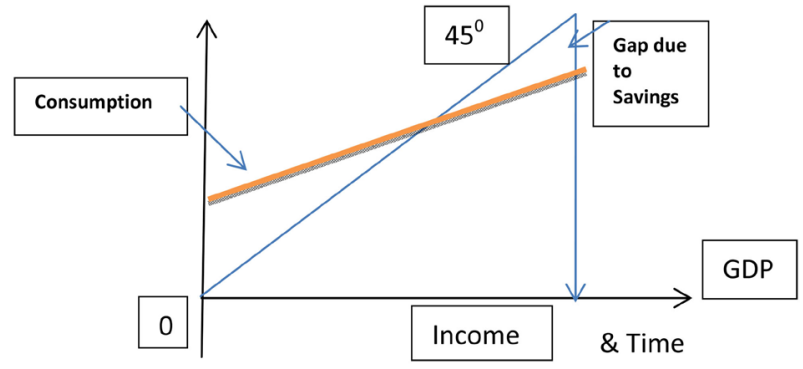

Figure 5. Income and consumption. Source: Samuelson's Cross.

\subsection{The Marginal Propensity to Consume and Multiplier}

The marginal propensity to consume-MPC is such that when production increases, (from an increased employment in capital goods industry), the multiplier is $>1$, but not far away from 1 for Keynes [1]. The reverse is also true.

This is a stability condition for Keynes [1] found rational, as a psychological characteristic of human nature. He explains: as "real income" increases, the pressure from today needs falls, and a wider margin is created (above "standard level of living", being a floor for us); Savings increase. The reverse is also true.

Keynes persists: "experience shows that there are customs of psychological response that permit equilibrium [1]. The amount society spends on consumption $(\mathrm{Ct}+1)$ depends on subjective needs, psychological propensities, and habits. The subjective factors-mentioned above-include psychological characteristics of human nature and social practices and institutions, (which) if not steady, it is improbable to suffer a material change in the short run [1].

Keynes also believed that as employment increases, money wages tend to increase, but proportionally. This is his other stability convention for prices. The reverse is also true.

\subsection{Further Psychological Variables in Keynes}

The individual-for Keynes [1] - decides how much to consume at $\mathrm{t}$ and how much to consume at $\mathrm{t}+1$, retaining part of his/her income $\mathrm{Yt}-1$ from current consumption Ct.

Keynes was particularly concerned about the form this second part will take [1], including any past Savings. One possibility is cash (or its equivalent). $\mathrm{He}$ then asked, what is individual's "liquidity" preference? Or how much (income) a person wants to hold in cash? He defined the well-known "reward" for parting from liquidity: $r$, the "price" which brings equilibrium between a desire to hold wealth/income in cash and its existing quantity M".

$M$ now is created by the Central Bank. Let Mt be the quantity of money, $L t$ the liquidity preference and $r_{t}$ the rate of interest, then

$$
M t=L t\left(r_{t}\right)
$$

\subsection{The Marginal Utility of Capital}

The "marginal utility of capital" for Keynes [1] is $>0$, if investment is scarce in 
the long run. To have MEC $>r$, this depends on psychological and institutional conditions. In institutional conditions, Keynes [1], included the ones preventing $\mathrm{r}^{27}$ to $<$ than a minimum. Institutional and psychological factors set a limit - most probably-equal to $2 \%-2.5 \%$ in the long run (Figure 6). In USA, $r$ for investment, varied in 2018, from 4\% to $6 \%$ https://us.deposits.org/investing/

\subsection{Is r a Highly Psychological Phenomenon? Can $r$ Be Negative?}

For Keynes [1] $\mathrm{r}$ was a highly ... psychological phenomenon, but in next page [1] $\mathrm{r}$ was a highly conventional one. He argued that, in any given state of expectations, there is in the minds of public a certain potentiality towards holding $\operatorname{cash}^{28}$. The degree for this, depends on how much the monetary authorities are willing to create it (=supply of money, M).

\subsubsection{A Negative Rate of Interest?}

As shown (Figure 6), graphically $r<0$ or even $r=0$, are possible by simply shifting LM1 curve down to $\mathrm{LM}_{2}$, if permitted by M. Then, Savings (new and past) will be hoarded, as hoarding now costs 0 . Resources will stay idle. But the fact that $S=0$ will prevent even a positive investment.

Our theory is that IS will not cut LM2 below 0 , but it will stop at least at 0 (heavy IS) and $\mathrm{M}$ will not allow it (heavy LM), and most probably it will stop too at $r=0$ or $>0$, as Keynes said.

An $r<0$ means also costless loans to investors, but banks will have no incentive to provide them, though they are "paid" to keep bank deposits-if any (unless they want to minimize losses). As a risk \% enters in $r$, this means also a riskless economy and zero uncertainty.

We cannot believe that a central bank (and ECB in Europe, est. in 1998-1999-2002), would allow the creation of a substantial supply of money (M) so that $r<0$. As shown, GDP increased (doubled; Y2) at an $r<0$ (Figure 6), but this is not real, as there $S=0$. Many banks will get bankrupt.

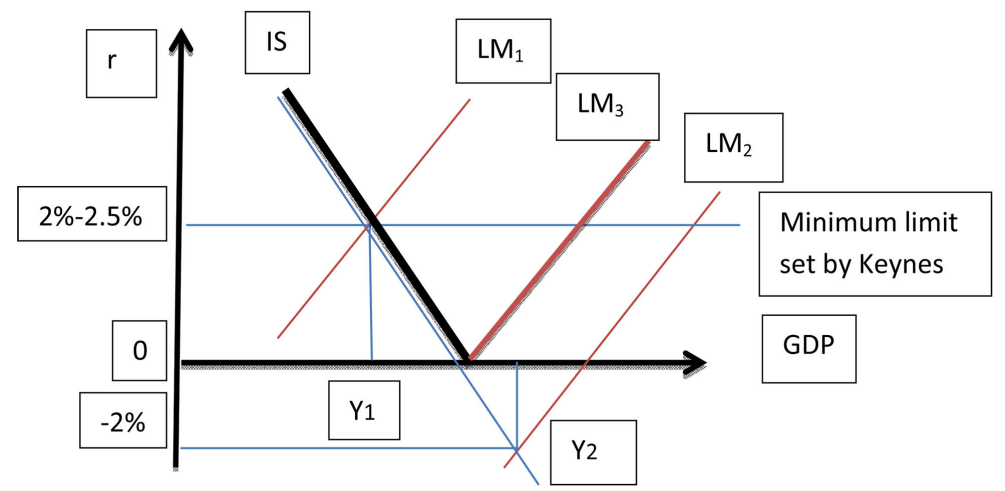

Figure 6. An economy with a negative r. Source: author.

${ }^{27}$ After GFC, $\mathrm{r}$ on cash deposits fell in 2018 to $-0.75 \%$ in Switzerland and -0.10 in Japan (from $9 \%$ in 1972); France, Germany, Italy, Netherlands and Spain: 0\%. UK: 0.5\% and USA: 2\%. Greece: $0.75 \%$ for $€ 5000+$ for a rather long tenor.

${ }^{28}$ Beyond "transaction and/or precautionary" motives. 
Keynes assumed there to be a certain cost for banks to bring borrowers and lenders together; plus the fact that there is "uncertainty" about future r [1]. So, $r$ entering into MEC calculations for new investments, will be increased by a certain \% for uncertainty about its future level.

Banks, we believe, are happy to lower $r$ on cash deposits (call accounts) and on all deposits, as this increases the gap of what they charge on personal loans and on credit cards (max. 21\% in Greece) and on what they lend. They are not happy to reduce $r$, in lending investors, at or below 0 , we reckon!

\subsubsection{Liquidity Trap}

Robinson D (in 1940) argued that a "liquidity trap" in Keynes' model is set, meaning that $r$ cannot be made to fall below a certain MEC, through increasing M. Moreover, M will be controlled, so that money to be scarce. A "liquidity trap" depends more on $\mathrm{M}$, than on $\mathrm{L}$, in our opinion.

More correctly, a liquidity trap exists, if when $\mathrm{MEC}=\mathrm{r}, \mathrm{r}$ cannot be made to go further down by increasing $\mathrm{M}$, so that $\mathrm{r}$ to be $<\mathrm{MEC}$, and thus an increased investment to be caused. We consider $r$ to be more flexible and a key, than MEC, which cannot easily be managed. If $r=0$, then the entire investment theoretically will (qualify to) be carried-out-provided MEC $>0>\mathrm{r}$ - and M (as well S) are at the levels required.

We saw that ECB cared for all European banks to survive during GFC. USA did the same, except for 1 - 2 cases, i.e. those of Lehman Bros and AIG-American International Group. Collapse of the entire banking sector means collapse of one pillar of capitalism; this, we believe, will be not allowed by ECB (or FED) - though an individual bank may be allowed to collapse, especially if deviates tomorrow from "Basel III" rules.

\subsection{Stability in Keynes' Economic System}

Keynes devoted a number of pages to establish that his economic system is stable. For stability, the basis is ... "human nature". As the struggle for money wages-affecting prices-is concerned, for maintaining a high (relative) wage, this is a ... psychological law [1]. Keynes believed that moderate changes in MEC, or in $r$, will not be related to large changes in investment. The higher investment acts adversely ${ }^{29}$ on MEC (if homogeneous products are produced -for us) by increasing the capital stock.

Keynes believed strongly in a "diminishing MEC", out of the law of supply, which surely is not valid with an "innovative" investment. A cost-reducinginvestment will increase MEC, and it will reduce total capital (i.e. the identical capital of a higher cost will be eliminated, given total demand). Unfortunately, Keynes assumed no technical progress ${ }^{30}$, writing for the short run.

${ }^{29} \mathrm{~A}$ higher demand for capital goods implies higher prices, and thus a lower ME. Also a higher supply of goods will entail lower prices and thus lower ME.

${ }^{30}$ Keynes [1] assumed a given organization, equipment and techniques. However he could not resist the challenge to write about capital vintages. 
But investments of various vintages compete ... like wines; the newer capital good $^{31}$ competes with the older [1] [24] [25]. This is especially true for ships ${ }^{32}$, houses, and between older and younger men ... As put by Ackley [26] to discuss economic growth with no "technological change" is like missing the essence of the matter.

\section{PART III: KEYNES' Microeconomics}

This part dismisses the argument that Keynes lacked a microeconomic theory. Perhaps his microeconomic theory here needs a certain expansion. Keynes [1] described the psychology of entrepreneurs which, by the way, corresponds ... to that of nowadays Greek shipowners. Greek shipowners-except for a small minority-did not resort to Stock Exchanges, since 2006 or so, for the fear of losing control of their company.

\subsection{Pre-Stock Exchange Business Practices-Today's Greek Shipowners}

As described by Keynes, in the pre-Stock exchange period in UK (summarized): "When enterprises owned by those who undertook them ${ }^{33}$, investment depended on a sufficient supply of individuals of sanguine temperament, and constructive impulses, who embarked on business as a way of life" 34 ... "But no one would know, at the end, whether the average results exceeded, equaled or fell short of the prevailing rate of interest".

"It is possible that the results of investments disappointed the hopes prompted them. Business is a game of skill, and chance, with unknown results. If human nature felt no temptation to take a chance, no satisfaction (which could be derived from $)^{35}$-apart from profit-from constructing ${ }^{36}$ a factory, a mine, a railway or a farm, there could be not much investment"!

\subsection{Animal Spirits}

Looking [1] at another "characteristic of human nature", a large proportion of positive activities depends on spontaneous optimism-moral, hedonistic or economic. Decisions to do something positive can only be taken as a result of animal spirits-a spontaneous urge to act". Humans want rather to act than not to act.

"The individual initiative will only be adequate when a reasonable calculation

\footnotetext{
${ }^{31}$ This happens and among newer products vis-à-vis older identical ones.

${ }^{32} \mathrm{~A} 2^{\text {nd }}$ hand ship does not have necessarily a higher total cost vis-à-vis a similar new! Important is the "homogeneity" of transport services despite the age of vessel. So, homogeneity of services is what matters, not vintage. Things have changed, however, on charterers' "fear" that older vessels are more prone to marine accidents as mentioned!

${ }^{33}$ Meaning original owners, where management and ownership coincided.

${ }^{34}$ Greeks have ship-owning as a "way of life".

${ }^{35} \mathrm{Phrase}$ in brackets added to complete the sentence.

${ }^{36}$ Keynes on purpose-we believe-mentions these difficult and large projects for his time requiring a lot of capital and bearing high risk, to make a greater impression.
} 
is supplemented and supported by animal spirits [1], so that the thought (about) (an) ultimate loss, which often overtakes pioneers, to be put aside-as a healthy man puts aside the expectation of death.

"Animal spirits are the moving power of investment, and not alone the exact 'net MEC'. Entrepreneurs remain stable because of their animal spirits, even "when the ocean is flat and they are subject to panics during storms" [1]. Keynes obviously had a particular agony for his system to be stable. "MEC is influenced from the sharp changes in business psychology, especially when investment increases".

\subsection{The Nature of Businessmen}

Moreover, "major investments are usually undertaken on the strength of the hunches of entrepreneurs, despite (any) uncertainties; these would make a rational and cautious person about $\mathrm{r}$ and profit, to postpone his/her decision; (but) there, an opportunity is grasped by (those) whoever have the courage to try".

Keynes [1], we reckon, imagined entrepreneurs to contemplate a number of investment plans-expecting from each plan a calculated efficiency-and to wait a proper $r$ for the plans to be started, induced by their animal spirits. Entrepreneurs, in calculating-out MEC, took into account their long-period expectations and especially: the state of confidence [1], deducting from MEC (or adding to $r$ ) the $\%$ for risk and uncertainty for $r$ to be encountered in project's life time till it scrapped.

We may include in MEC a positive \% p.a. representing "animal spirits". Confidence or rather uncertainty may also be represented by a $\%$, where a $100 \%$ of MEC calculations will stand for certainty. Clearly, Governments have to "provide" low annual costs of production due to State, low country risks and high confidence. Entrepreneurs calculate the effective demand for their products to be produced by capital over capital's life.

\subsection{Supplementary Cost}

The excess of "expected depreciation" over "user's cost" is supplementary cost; and this has also a psychological influence on entrepreneurs [1].

\section{Part IV: Hicks' Curves}

Interesting is a correspondence ${ }^{37}$ between Hicks and Keynes over Hicks' article: "Mr. Keynes and the Classics" [27]. Hicks presented a diagram (known by now as "IS/LM") of how economy works in a more general way believing that this expressed ${ }^{38}$ Keynes.

${ }^{37}$ Hicks wrote: "My Dear Keynes, thank you for accepting my manuscript as true of your views" ... Keynes replied: "My Dear Hicks, I am glad that you think your manuscript is good" ... ${ }^{38}$ Harrod R. (1900-1978), however, was, admittedly, the one that understood Keynes completely in 1935, at a time when he read the proofs of General Theory. 


\subsection{Keynes' Mistake in Treating Capital?}

Prof. Krimpas [28] argued that Keynes committed a mistake in treating capital ... Keynes wrote [1]: "for each type of capital (meaning the same capital) we can build up a schedule, showing by how much investment in it (meaning the "amount added to this capital" producing the same goods [1], will have to increase, within the period, in order that its ("marginal") efficiency should fall to any given figure" ( $\mathrm{r}$ was not mentioned!) (bolds, ("') and words in parentheses added).

The above means that:

$$
I t=f(\text { Efficiency })
$$

where It stands for investment; for us this is a supply curve of one investment ... Let us draw this schedule (not drawn by Keynes ...) (Figure 7).

In Figure 7, if we increase investment-in value-from $0 \mathrm{P}$ to $0 \mathrm{Q}$, its efficiency will fall to 5\%. For Krimpas [28], the curve II expresses the "demand" for investment. But in that case, we believe, $r$ should not be absent. At this point Keynes, we believe, implicitly "distinguished" capital = a stock, from investment $=\mathrm{a}$ flow. And most important ${ }^{39}$ he defined that MEC $=$ the efficiency of Investment. Perhaps, Keynes had in mind to use the diminishing efficiency of capital for the explanation of business cycle.

But Keynes, unfortunately, - like Marx-avoided incorporating "technological progress" in his model, done afterwards by: Harrod (in 1939; and in 1949), Domar (in 1953) and Solow (in 1957). Prof. Krimpas [28], moreover, argued that curve II (in Figure 7) is a forward falling curve like a proper, classical, demand ... which could enable one-like Hicks-to generate-i.e. via an IS/LM diagram-an overall working equilibrium (i.e. Figure 8) ... He was right now.

Keynes, we believe, wrote about "marginal efficiency of a capital type X" meaning the "efficiency of investment" in a further capital good, but as the one before. For if we paid attention to the term "marginal"-which means a small addition of a flow on to a stock (i.e. investment It added to capital X)-there would have been no misunderstandings.

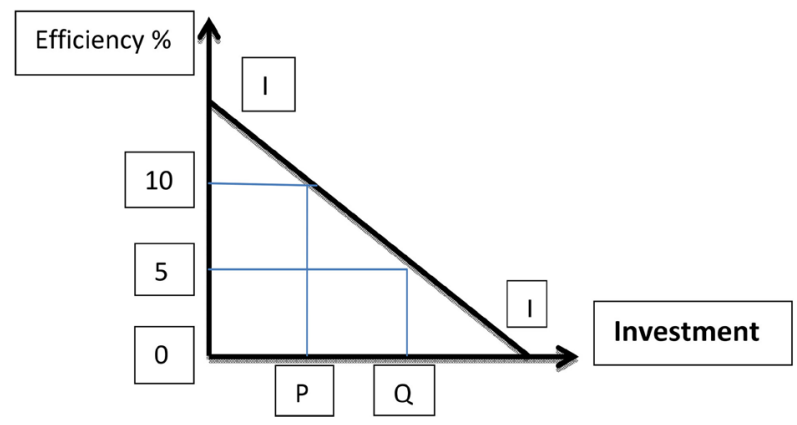

Figure 7. Keynes' schedule of MEC. Source: author.

${ }^{39}$ The "Marginal efficiency of capital" is better defined as the increase in total efficiency of capital from one additional unit of capital (but this = investment). We may say that investment is equal to the marginal product of capital. 


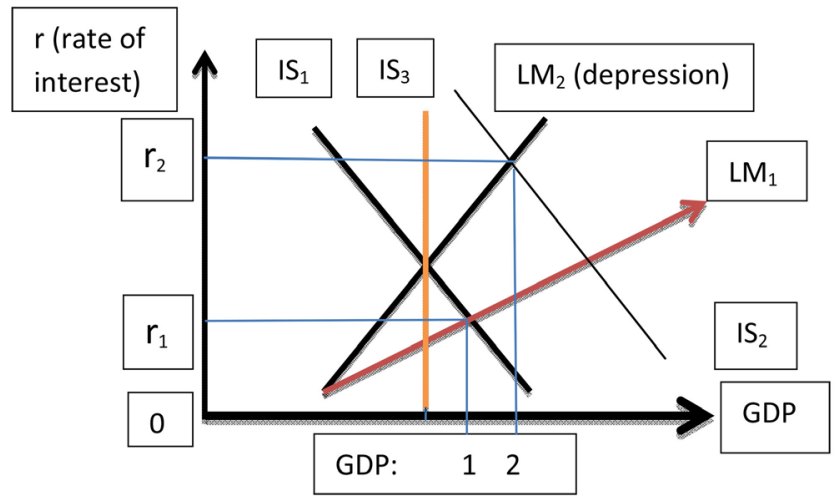

Figure 8. IS/LM Hicks' curves. Source: author.

\subsection{Hicks Curves}

Hicks [27] wanted to integrate Keynes' four markets into one-(Figure 8) - r, national income, goods market and money market!

IS curve relates national income, $\mathrm{Yt}$, to $\mathrm{r}_{\mathrm{t}}$, with equilibrium in "goods' market". All points on IS curve, indicate equilibrium in the markets of goods, making Savers and Investors happy from what is produced ... As GDP increases, demand for money increases to LM2 and $r_{1}$ increases to $r_{2}$. Later IS is defined to include "governmental spending". An increase in "governmental spending", shifts IS1 right, to IS 2 , GDP increases (2), demand for money increases (people sell bonds); $r$ increases. Hicks drew also LM curve, which above is shown to shift left (Figure 8). All points on an LM curve indicate equilibrium in money market, where wealth holders are happy with the money they hold. It shows that the demand for money is equal to the supply of money. Prices are constant. A left shift of the LM curve indicates depression, as GDP is lower (from 2 to 1 ).

If there is a liquidity trap, $\mathrm{r}$ does not influence investment, e.g. assuming $\mathrm{IS}_{3}$; even if $\mathrm{r}$ falls to $0 \%$, investment will not be forthcoming. Figure 8 can also be used if we have withdrawals/taxation.

\section{Part V: Eurozone, Greece and Global Financial Crisis}

Prices in Eurozone fell below the level they had in the pre-industrial period, and the "Gold Standard" returned, as parities in Eurozone are (nearly) fixed ([3], p. 7). Keynes ${ }^{40}$ supported the theory of the "export-led growth" ${ }^{41}$ after $2^{\text {nd }} \mathrm{WW}$, a similar global situation in which world was after 2009! GFC started from USA banking system [30] [31] [32] and spread round the world by the system of making tradeable titles out of claims for debts (sub-prime mortgage loans).

Eurozone-of 17 out of 27 countries in 2012-provided loans to the countries of S Europe, causing rapid increase in ... German exports. When countries have debts, their growth is slower. The problem with Greece-10 years in depression so far-and with Ireland, Italy, Portugal and Spain, is that they are not as com${ }^{40}$ The Economic Consequences of Peace, in 1919, Macmillan.

${ }^{41}$ Technical progress leads to an expansion of production, but "living standards" do not increase as fast as production, so firms have to export. This policy followed by Japan and China. 
petitive ... as Germany. Moreover, being in Europe, they are unable to devalue currency. Also, $r$ is determined by CEB. So, most of Keynes' artillery ${ }^{42}$ is not in the hands of the individual countries of the Eurozone.

To become competitive, the $\operatorname{cost}^{43}$ of domestic production has to fall in real terms-and especially wage cost-for economic growth to return. This is the "austerity" policy. In Greece, wages fell 19\% (2010-2017; ETUI); GFC left $\sim 89 \mathrm{~b}$ of "red loans" ... in Greek banks in end 2018. "Fixed" exchange rates dictate contractionary policies.

Keynes encountered a similar situation in 1931. For Keynes global spending was necessary to avoid global recession [1], and thus lending to countries required to direct money to other countries' exports. If borrowing from Eurozone is not possible, then borrowing from markets is (?). In 2012 countries could not borrow from markets. Greece hopes to be able to borrow from markets in 2019.

Keynes supported Governmental spending, when firms are reluctant to invest, so that employment to be maintained (Figure 9). Moreover, when Monetary Policy is not available, fiscal policy is.

On vertical axis, Savings are shown, Investment and Governmental spending; on horizontal axis GDP. If "Governmental spending" increases from $0 \mathrm{E}$ to $0 \mathrm{D}$, and spending 1 curve shifts to spending 2 , it cuts "Savings + function", $G_{1}$, at a higher GDP $(0 \mathrm{~K}<0 \mathrm{~L})$. Savings, as a result, production and GDP increase.

"The paradox of thrift ${ }^{44}$ " is also shown by shifting "Savings + curve" (heavy black line) left. A depression occurs when GDP falls from $0 \mathrm{M}$ to $0 \mathrm{~K}$. An amount of labor is not required. The Keynesian multiplier is $=\mathrm{KL} / \mathrm{ED}<1$. The flatter the "Savings + function", $\mathrm{G}_{2}$, the greater the multiplier: i.e. KL/ED < LM/ED > 1. Greater Savings mean greater income (and higher production), if Savings are invested.

Eurozone countries suffered from GFC-in end 2008. This forced firms and workers to save; lack of spending reduced $r$ to $0 \%$-or even below-in bank deposits ... GDP equalized the markets of goods $s^{45}$ making Savings equal to Investment $(\mathrm{I}=\mathrm{S})$. Involuntary unemployment ${ }^{46}$ created. Increased Savings reduced GDP, causing also failure in the "product" market.

Certain countries, like USA, reduced taxes, which is a more effective measure if applied to low wage workers, inducing them to consume-so that production to increase. Unemployment for the Classics was due to labor market, while for Keynes was due to product market; due to Savings, firms do not collect what they have spent (creation of unsold goods) and so reduce next production.

The Swan diagram-SD [3] (Figure 10) is used when the economy is open, presupposing also full employment (a model due also to Solow). The SD shows:

\footnotetext{
${ }^{42}$ Devaluation, so that to boost exports and reduce imports; tariffs, to protect national products and boost exports (!); government to spend on public works (=Keynesian expansion).

${ }^{43}$ This suggests replacing imports by domestic production.

${ }^{44}$ The desire to save more, means ... a lower GDP.

${ }^{45}$ Marshall believed that this was a job for prices.

${ }^{46}$ People want to work, but there are no jobs.
} 
how to have an "exchange rate" necessary to ensure external balance and how to have a "domestic macroeconomic policy" necessary to ensure internal balancejointly determined. On vertical axis, the "nominal exchange rate times the ratio of prices at home and abroad" is shown.

If we are in area 1 , we achieved unemployment \& deficit; in 2, inflation \& deficit; in 3, inflation \& surplus, and in 4, unemployment \& surplus. In full capital mobility (Eurozone), r cannot be influenced by the central bank of any country-member, and thus there is no room for a national monetary policy. Countries in debt have to achieve "external balance", by austerity, as mentioned lowering also domestic prices.

Austerity intensifies foreign debt and moves countries to left in Figure 10 by reducing domestic spending-home demand-and creating surplus in the current account to repay the debt. This creates unemployment (area 4). Austerity provides room for extra exports and the possibility for home-made goods to replace the imported ones...

Greece imported mainly (2016) raw materials, oil and equipment. Unemployed amounted to 862,500 (23\%), with the analogous loss of effective demand. Wages $^{47}$ fell. Exports ( $\left.\$ 26.5 \mathrm{~b}\right)$ increased $(\sim 14 \%$ on GDP). Thirty \% of imports consisted of: crude oil $(\sim 13 \%)$; refined products $(5 \%)$; medicines $\sim 5 \%$; coastal and cargo ships $4.5 \%$ and $\operatorname{cars}^{48} 2.5 \%$ ! Greece should expand its own pharmaceutical industry, car industry and shipyards, buying also foreign knowhow.

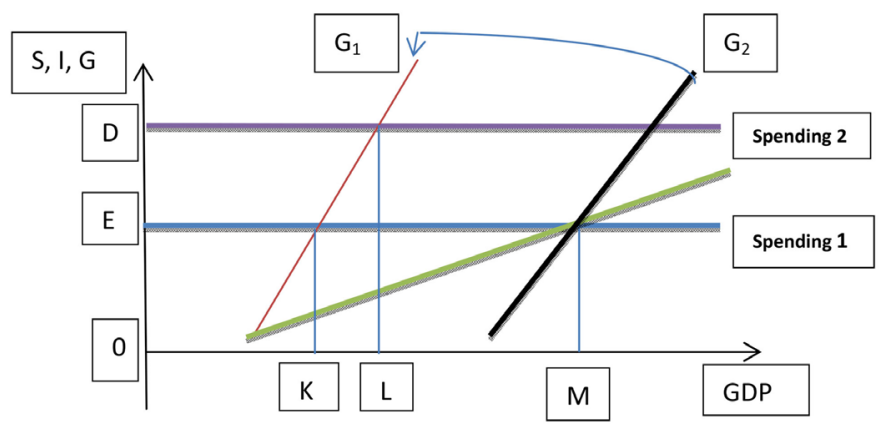

Figure 9. The effect of Governmental spending. Source: Modified from [3].

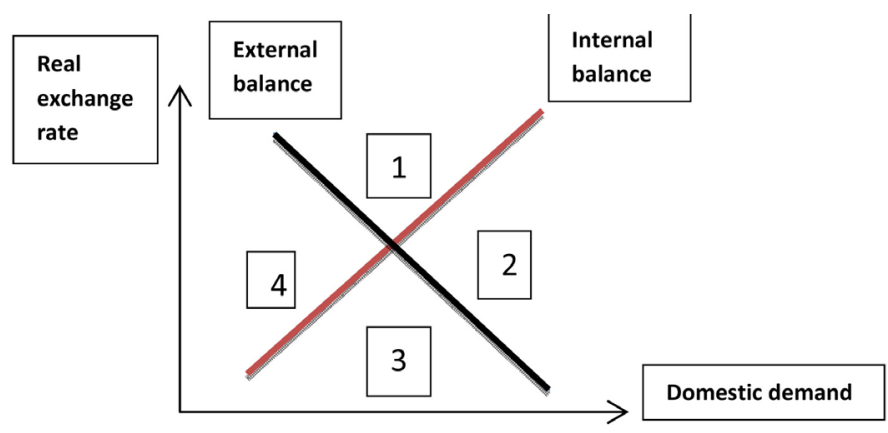

Figure 10. The Swan diagram. Source: modified from [3].

\footnotetext{
${ }^{47}$ Germany pays $€ 1768$ per month.

${ }^{48}$ Expected to rise to 150,000 per annum.
} 
As Germany did, Greece has to import technology from USA. Crude oil imports should be replaced by other sources of energy, as the present explorations for Greek oil and gas will concern next generations, we believe, and gas from Russia will not be as cheap as required. For the "export-led growth strategy", the "internal balance curve" (Figure 10) must shift left, as Germany did.

\section{Concluding Remarks}

Economics owes much to Psychology. Keynes tried to make it also a science explaining real life. The microeconomic psychology concerning utility did not satisfy us, and Samuelson, and thus it has a progress to make to create a real "theory of wants".

Though economics established for solving the asymmetry between the plethora of needs and the limited means-a problem first put forward in 1798 by Malthus (1766-1834) ${ }^{49}$ - it failed to define the quality of goods.

We doubt if: food produced is healthy; human and animal diseases diminished; radiation-released from nuclear accidents—did not multiply cancer incidents all over Europe and Japan; the environment we live is a killer. Obviously, new economic objectives have to be adopted soon.

Some argue that modern economics are by far superior: it created "happiness economics", i.e. a study of the relationship between human satisfaction and employment, wealth ... It has, after WW 2, defined quality of life, i.e. a measure of happiness again ... Humans ... today, it is argued, are happier, because they have financial security, job satisfaction, family life ... But what about car accidents, deaths from drugs, crimes, and Terrorism as well Piracy?

Marketing-our hope for something better than economics-moved in the same line by saying: "quality is the totality of features and characteristics of a product that bear on its ability to satisfy (stated or implied) needs [29] (bolds added) $\ldots$

Humans today go to a "super market" with a shopping list, and a maximum amount of money in mind; satisfaction comes when goods are consumed, and there is no mechanism at home to measure it... and moreover, purchases have been already accomplished. One knows what needs has-and assumes ${ }^{50}$ that goods bought will be able to satisfy them. Regrets exist.

The concept of utility originated in Bentham J (1748-1832), who argued that the needs of human beings are confined in mater, and utility is-at one and the same time-a feeling of happiness that individuals do, in fact, strive to maximize and that they, and society as a whole, should strive to maximize ...

The $19^{\text {th }}$ century economists expected, in vain, that a devise for measuring utility would eventually emerge from psychological research. The matter of hu-

\footnotetext{
${ }^{49}$ Malthus argued that a numerous and increasing population is not synonymous with wealth, as it was believed, due to the limited food supplies that this entails. Malthus T.R. (1970). An Essay on the Principles of Population and A summary view of the principles of population, edited by A Flew with an introduction, Penguin Books

${ }^{50}$ Regrets are probable when advertising is misleading.
} 
man utility is still open. Why humans need goods? Smith answered: for biological reasons. And this is independent of whether a good releases pleasure ${ }^{51} \ldots$ The whole issue of utility triggered Samuelson (1915- ) in 1948 to provide his own theory ${ }^{52}$.

Economy with plentiful or free goods means also some wastage of resources to a certain degree, something economic science should have better observed. $\mathrm{Hu}$ mans realized after many decades that even recycled materials are useful. $\mathrm{Hu}$ mans, we believe, do not know how to manage, wisely, abundance, as they failed to manage e.g. un-renewable resources (fossil fuels), and failed to show respect to earth's climate (city pollution; climate change, greenhouse effect, increase in earth's temperature, frequency of hurricanes like Florence, etc.).

Economists-to be pleasant, we believe-added a lot of good aspects: they established satisfaction, called also happiness, which can be maximized! Economists shout, after Epicurus-the Greek philosopher: "let us eat and drink, for tomorrow we die". Similarly, Keynes shouted: "in the long run we are all dead"53 let live in the short run. The disutility of labor is compensated by the pleasure from consuming goods, as far as income can buy, given prices.

But is economic life fair? The essential economic variables of income and wealth are not! Out of 100 persons, only 3 get the maximum from life in terms of income and wealth ... (="Pareto's power law"). The level of income and prices make life even harder, if the later are high and the former is low. Involuntary unemployment deprives people wanting to work from means. Wars create involuntary immigration and a certain religion creates clashes among nationalities. Economists created an alibi by saying that they do not have to deal with what "should be" ("normative economics").

Universities have to prepare suitable personalities for their country to have a prospect for development. Keynes suggested to entrepreneurs to take risks. Entrepreneurs see a need to come and are prepared to satisfy it (like Chandris A-a shipowner). Keynesian entrepreneurs do not pay a decisive importance on "expected (net) MEC", but on the fact that they wake-up every morning and ask: "what new businesses are we going to embark on today"? What is the level of $r$ ? What MECs have we?

\section{Conflicts of Interest}

The author declares no conflicts of interest regarding the publication of this paper.

\section{References}

[1] Keynes, J.M. (1936) The General Theory of Employment, Interest and Money. 1961 Reprint, Macmillan \& Co Ltd, London.

[2] Blaug, M. (1997) Economic Theory in Retrospect. 5th Edition, Cambridge University Press, Cambridge. https://doi.org/10.1017/CBO9780511805639

\footnotetext{
${ }^{51} \mathrm{~A}$ bitter medicine releases displeasure, but it may help one to live.

52" How consumers react to changes in prices and incomes".

53“A tract on monetary reform", in 1923, chap. 3.
} 
[3] Temin, P. and Vines, D. (2014) Keynes: Useful Economics for the World Economy. MIT Press, Cambridge, MA.

[4] Gossen, H.H. (1854; 1983) Laws of Human Relations and the Rules of Human Action Derived Therefrom, Translated from German. MIT Press, Cambridge, MA.

[5] Bowley, A.L. (1924) The Mathematical Groundwork of Economics: An Introductory Treatise. Clarendon Press, London.

[6] Johnson, W.E. (1913) The Pure Theory of Utility Curves. Economic Journal, 23, 483-513. https://doi.org/10.2307/2221661

[7] Slutsky, E. (1915) On the Theory of Equilibrium of Consumers, (Title translated by author from Italian). Giornalle degli economisti (Journal of Economists), 51, 1-26.

[8] Blinder, A. (1988) The Fall and Rise of Keynesian Economics. Economic Record, 64, 278-294. https://doi.org/10.1111/j.1475-4932.1988.tb02067.x

[9] Goulielmos, A.M. (2013) Keynes Economics of Depression: The Shipping Industry as a Case-Study. Journal of Research in Economics and International Finance, 2, 13-28.

[10] Pearce, D.W. (1992; General Editor) Dictionary of Modern Economics. The Macmillan Press, London.

[11] Goulielmos, A.M. (2018) The Economics of Wealth According to Economic and Religious Principles. Modern Economy, 9, 1465-1489. https://doi.org/10.4236/me.2018.98093

[12] Jennings, R. (1855; 1969) Natural Elements of Political Economy. A.M. Kelley, New York.

[13] Marshall, A. (1920) Principles of Economics. 8th Edition, reprint 1961, Macmillan \& Co Ltd, London.

[14] Schroeder, M. (2009) Fractals, Chaos, Power Laws: Minutes from an Infinite Paradise. Dover Publications, Inc., a Republication of the Work Originally Published in 1991.

[15] Stevens, S.S. (1969) On Predicting Exponents for Cross-Modality Matches. Perception \& Psychophysics, 6, 251-256. https://doi.org/10.3758/BF03207028

[16] Robinson, J. and Eatwell, J. (1973) An Introduction to Modern Economics. McGraw-Hill, New York.

[17] Samuelson, P. (1948) Consumption Theory in Terms of Revealed Preferences. Economica, 15, 243-253. https://doi.org/10.2307/2549561

[18] Csikszentmihalyi, M. (1992) Flow: The Psychology of Happiness. Rider.

[19] Battram, A. (1998) Navigating Complexity: The Essential Guide to Complexity Theory in Business and Management. The Industrial Society.

[20] Robinson, J. (1964) Essays in the Theory of Economic Growth. Macmillan, London.

[21] Priesmeyer, H.R. (1992) Organizations and Chaos: Defining the Methods of Nonlinear Management. Quorum Books, London.

[22] Mandelbrot, B. and Hudson, R.L. (2006) The (Mis)Behavior of Markets: A Fractal View of Financial Turbulence. Basic Books, New York.

[23] Shaw, S. (2004) Airline Marketing and Management. 5th Edition, Ashgate, Farnham.

[24] Goulielmos, A.M. (1974) A Vintage Model Approach to Some Problems of Shipping Economics. Unpublished PhD Thesis, Brunel University, London.

[25] Salter, W.E.G. (1966) Productivity and Technical Change. Cambridge University Press, London. 
[26] Ackley, G. (1961) Macroeconomic Theory. Macmillan Co., London.

[27] Hicks, J.R. (1937) Mr. Keynes and the Classics. Econometrica, 5, 147-159.

[28] Krimpas, G.E. (1974) Keynes' General Theory. Athens (a Monograph).

[29] Kotler, P. (1994) Marketing Management: Analysis, Planning, Implementation, and Control. 8th Edition, Prentice Hall, Upper Saddle River.

https://doi.org/10.1515/9781400846641

[30] Temin, P. and Vines, D. (2013) The Leaderless Economy: Why the World Economic System Fell Apart and How to Fix It. Princeton University Press, Princeton.

[31] Wolf, M. (2014) The Shifts and the Shocks: What We've Learned and Have Still to Learn from the Financial Crisis. Penguin Press.

[32] Galbraith, J.K. (2014) The End of Normal: The Great Crisis and the Future of Growth. Simon and Schuster, New York. 


\section{Appendix: Keynes' Independent Variables}

The 1st independent variable is Consumption ( $4^{\text {th }}$ graph from left) (Figure A1). Consumption (DC) with Savings (CY) equal to, and determine, GDP. At 0 or at a very low GDP, all of it is consumed (touching the $45^{\circ}$ line). Gradually consumption increases, as GDP increases, but not as fast, allowing for increasing Savings. This part is dynamic, as we have introduced time.

In the entrepreneurial market-graph 2-investment is equal to $0 \mathrm{~A}$, if $\mathrm{r} 1$-the 2nd independent variable-is $<$ MEC1 (the 3rd independent variable). Investment does not start where $r=$ MEC (blue arrows), because when $r=$ MEC, investment $=0$. Investment $0 \mathrm{~A}$-in graph 3-determines GDP at Y1, if Savings are $0 \mathrm{~A}=\mathrm{CY}$ (from graph 4). To obtain a higher GDP, investment must increase to $\mathrm{OB}$, and to find there an equal amount of Savings; in order to have $\mathrm{r} 2<\mathrm{MEC} 2$, and investment $0 \mathrm{~B}$, Money supply—graph 1 -must be = M2 (higher).

In graph 1, "liquidity trap" is set along the flat part of the $\mathrm{L}$ curve. There, $\mathrm{M}$ is unable to bring $\mathrm{r}$ below, despite its increase. If Savings rise to $0 \mathrm{~B}$, and Investment is at $0 \mathrm{~A}$, GDP cannot increase (to Y2). The reverse is also true. This is the "Paradox of thrift".

If MEC changes, as a result Investment (=Savings) changes. The future MEC

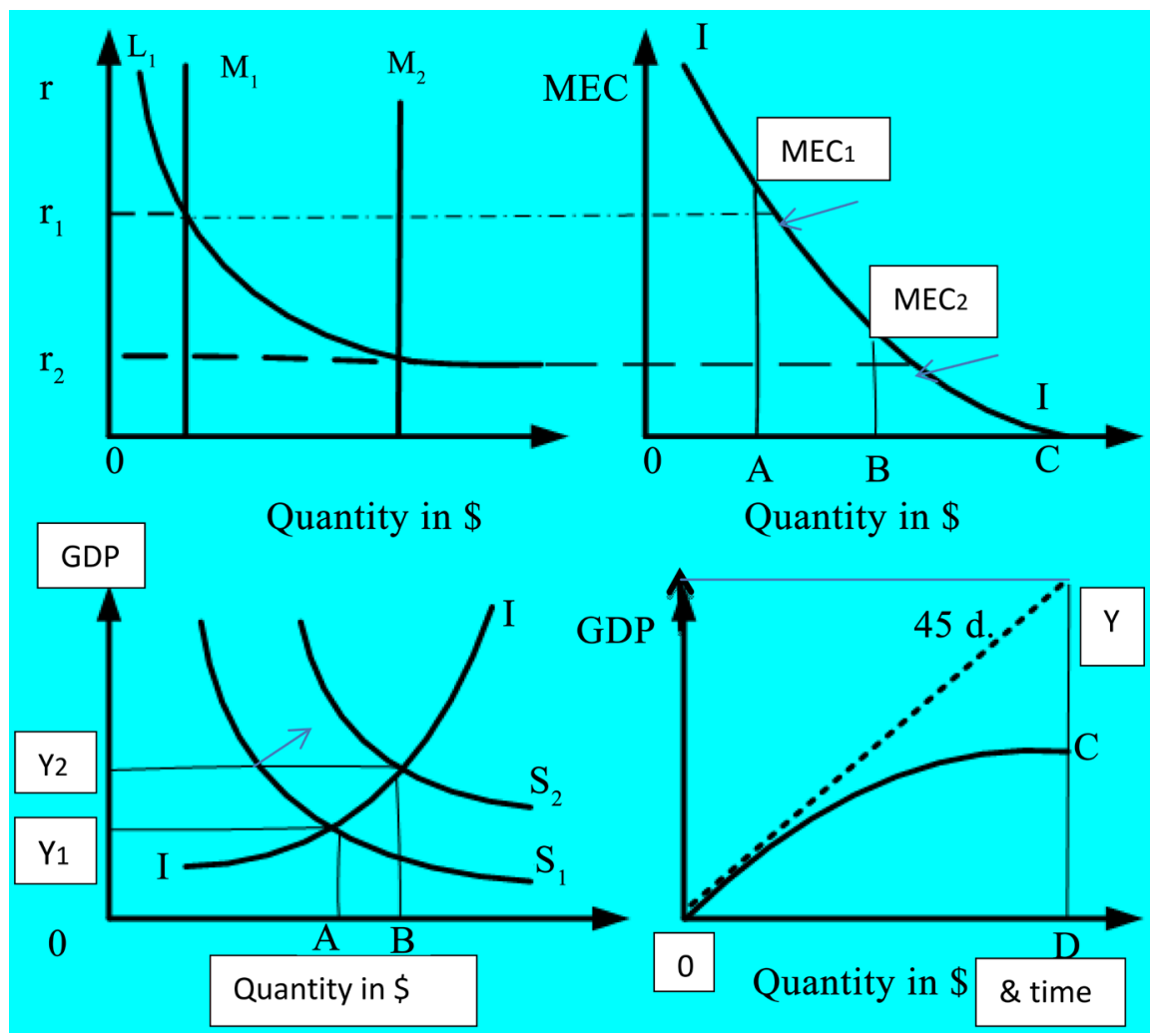

Figure A1. Keynes' 4 markets. Source: author.

${ }^{1}$ Keynes, apart from the 3 independent variables, he mentioned, ([1], Chap. 18), and 5 dependent variables: GDP, employment, expectations, quantity of equipment, and prospective yield. If the 5 factors change, they will cause shifts in the 3 curves above. 
-i.e. the expected one-is determined by the prices to be obtained by the goods produced, their quantities, the price of capital good today, the future costs of production, the expected life of capital good and its residual value. Also, by the real rate of interest (being also a discount factor) (the inflation is taken into account), risks involved, state of confidence, animal spirits, taxation ... as MEC is considered net for the whole life of the capital good. The (expected) life of new equipment is important and is related to its production as it may become obsolete as $t$ increases.

Important is that new equipment "cares" for its own replacement through depreciation. The longer the life of a capital good, the higher company's Savings, till capital good is scrapped (and replaced). Depreciation is the method of capitalism to perpetuate itself. But depreciation at historical cost is not enough for this end.

Keynes when talked about a "complex economic system" surely meant MEC and Capital. Consumption is rather predictable under psychological factors, determined by GDP, employment and wages; Savings is a residual activity of consumption, benefiting economy, if invested; $r$ can be controlled by Central bank (or ECB), which they have to care for $r$ to be $<\mathrm{MEC}$; Central bank also has to care for proper liquidity in the system. Investment is unpredictable.

Prices, determined by supply and demand-though assumed constant-are beneficial if they rise (along with wages, but not at an equal pace) to provide profits, given cost, provided they do not cut consumption. Growth depends on a higher effective demand (consumption and investment plus exports). Prices missing are: those of the capital goods; those of consumer's goods; wages. The demand for the first 2 is talked about, but not the supply of all 3.

Money supply - and foreign loans-indirectly influence GDP and r, getting it down to a minimum, which in turn influences investment, given MEC. In capitalistic system it is obvious that growth depends on investment-private or public-and on exports, given domestic prices and foreign exchange parity. The parity translates domestic prices to prices understood abroad.

Looking at graph 3, this gave the "Investment-Savings equilibrium" ... determining GDP. We have put together the "demand" (II) and the "supply" (savings) for investment ... This is better than IS. GDP increases due to II not Savings. 